\title{
Production of Cellulases by Bacillus cellulosilyticus Using Lignocellulosic Material
}

\author{
Bushra Maryam¹, Abdul Qadir ${ }^{1}$, Mariam Zameer ${ }^{1 *}$, Sajid Rashid Ahmad", \\ Rubina Nelofer ${ }^{2}$, Nadia Jamil ${ }^{1}$, Sameen Arzoo', Rubab Afzaal ${ }^{1}$ \\ ${ }^{1}$ College of Earth and Environmental Sciences, (CEES) University of Punjab, Quaid-e-Azam campus, Lahore \\ ${ }^{2}$ PCSIR Laboratories, Lahore
}

Received: 18 October 2017

Accepted: 28 November 2017

\begin{abstract}
The enzyme cellulase, a multi enzyme complex made up of several proteins, catalyses the conversion of cellulose to glucose in an enzymatic hydrolysis. In this study biomass alkali-pretreatment followed by enzymatic hydrolysis was carried out using crude cellulase enzyme produced from screened bacillus strain (Bacillus cellulosilyticus) having 1,998.79 IU/ml/min CMCase and 1,621.16 IU/ml/min FPase enzyme activity. The production of cellulase enzyme using an economical medium has been a significant achievement in the field of industrial biotechnology. The maximum yield of sugars in the form of total sugars $(179.84 \pm 0.2 \mathrm{mg} / \mathrm{ml})$, reducing sugars $(126.72 \pm 0.1 \mathrm{mg} / \mathrm{ml})$, and glucose $(105.40 \pm 0.1 \mathrm{mg} / \mathrm{ml})$ was achieved at $48 \mathrm{~h}$ incubation time, $50^{\circ} \mathrm{C}, 5 \mathrm{pH}, 6 \%$ enzyme concentration, $4 \%$ substrate loading, and PEG 3350 as a surfactant.
\end{abstract}

Keywords: Bacillus cellulosilyticus, Cellulases, hydrolysis, optimization

\section{Introduction}

Cellulases are the most useful enzymes in industry. They can be produced by fungi, bacteria, or actinomycetes. The high cost of cellulases is mainly due to the substrates used in production, and also the slow growth rate of fungi. Most of the research on cellulase production has focused on fungi, with relatively lesser stress on bacteria [1]. Bacteria, which have high growth rates compared to fungi, have good potential to be used in cellulase production [2]. Also, bacteria, owing to their diversity and rapid growth, can produce both alkalistable and temperature-stable enzymes, which can be

\footnotetext{
*e-mail: mariyambukhari@gmail.com
}

very important from an industrial point of view [3]. Cellulases produced by bacteria are often more effective catalysts. They may also be less inhibited by the presence of material that has already been hydrolyzed (feedback inhibition) [2]. Bacillus cellulosilyticus, Alkaliphilic Bacillus species has important industrial applications due to its ability to produce alkaline enzymes such as cellulase [4]. It produced extracellular enzymes that are resistant to high $\mathrm{pH}$ and high temperature conditions [4-6].

Cellulose, hemicelluloses, and lignin are major components of the lignocellulosic biomass. Cellulose binds tightly with lignin and hemicellulose. For efficient hydrolysis of cellulose, lignin components must be separated in order to make cellulose more accessible to the enzymes [7]. Prior to enzymatic hydrolysis, pretreatment is an important tool for practical cellulose 
conversion processes. Pre-treatment is required to alter the structure of cellulosic biomass to make cellulose more accessible to the enzyme that converts the carbohydrate polymers into fermentable sugars. The goal is to break the lignin seal and disrupt the crystalline structure of cellulose. Pretreatment also has great potential for improvement of efficiency and lowering of cost through research and development [8].

In the present research work, biomass alkali pretreatment followed by enzymatic hydrolysis was carried out using crude cellulase enzyme produced from screened bacillus strain Bacillus cellulosilyticus as well as to evaluate chemical composition of yard waste and to optimize enzymatic hydrolysis.

\section{Experimental Procedures}

\section{Bacterial Cultures}

Five celluloytic strains of Bacillus cellulosilyticus, named PC-BC1, PC-BC3, PC-BC4, PC-BC6, and $\mathrm{PC}-\mathrm{BC} 8$ were obtained from the culture collection center of the Food and Biotechnology Research Centre, PCSIR Labs Complex Lahore. The strains were revived on nutrient agar slants for $48 \mathrm{~h}$ at $30 \pm 5^{\circ} \mathrm{C}$ and preserved at $4^{\circ} \mathrm{C}$ and subcultured monthly.

\section{Plate Screening for Cellulase Enzyme}

Pure cultures of all bacterial strains were separately transferred in CMC agar plates for plate screening by streak method and incubated at $30 \pm 5^{\circ} \mathrm{C}$ for 2 days to allow for the secretion of cellulase. After 2 days, the agar medium was flooded with aqueous solution of Congo red dye $(1 \% \mathrm{w} / \mathrm{v})$ for 15 minutes to visualize the hydrolysis zones. Then Congo red solution was poured off, and the plates were flooded with $1 \mathrm{M} \mathrm{NaCl}$ solution for $15 \mathrm{~min}$. To indicate the cellulase activity of the bateria, diameters of clear zones around colonies on CMC agar were measured. The ratio of clear zone diameter to colony diameter was measured in order to select for the highest cellulase activity producer. The largest ratio was assumed to contain the highest activity. Among all Bacillus strains, PC-BC6 was selected as the one showing the highest cellulose degrading ability.

\section{Substrate Collection}

Yard waste (containing Bermuda grass, tree leaves, plant stems, herbs, dry leaves) was selected as the lignocellulosic raw material. This substrate was collected from the College of Earth and Environmental Sciences (CEES), University of the Punjab. The material was sun-dried, chopped, and pulverized in a hammer bitter mill, and then sieved by maintaining $2 \mathrm{~mm}$ mesh size.

\section{Alkaline Pretreatment of Substrate}

Yard waste was pretreated to remove the lignin content from substrate [9-10]. For alkaline pretreatment, $400 \mathrm{~g}$ of ground dry substrate was taken in a 3,000 ml flask and soaked in $4 \mathrm{ml}$ of $2.5 \% \mathrm{NaOH}$ for 2 hours at room temperature. It was then autoclaved at $121^{\circ} \mathrm{C}$ for 60 minutes. After that, the digested sample was recovered by filtration as the sample was filtered through muslin cloth and washed with distilled water 5-6 times to get $\mathrm{pH} 7.0$. Then residues were oven dried at $60-80^{\circ} \mathrm{C}$ overnight, packed in polypropylene bags, and stored in desiccators until use.

\section{Proximate Analysis}

Yard waste was subjected to proximate analysis under the standard experimental conditions according to standard method [11] for determining the percentage of moisture, ash, lignin, and cellulose content in context to investigate the chemical composition of the substrate under experimentation.

\section{Determining Percentage Moisture Content and Ash Test}

Moisture content of yard waste was measured by simple standard method [11]. "Ash content" is a measure of the total amount of minerals present within a biomass. Ash of the pretreated and control samples were calculated according to the standard method [11].

\section{Lignin Test}

The lignin content in treated and untreated samples was measured [12]. One gram of sample $\left(\mathrm{W}_{1}\right)$ was taken in $250 \mathrm{ml}$ round bottom digestion flask and $70 \mathrm{ml}$ of $1.25 \%$ of $\mathrm{H}_{2} \mathrm{SO}_{4}$ was added to reflux the sample for 2 hours. After refluxing, the sample was filtered and residues obtained on filter paper were taken in $250 \mathrm{ml}$ flask and $30 \mathrm{ml}$ of $72 \%$ conc. $\mathrm{H}_{2} \mathrm{SO}_{4}$ was added and mixed with a magnetic stirrer for 15 minutes. Excess water was added to dilute the sample, and filtered. The residues were taken in crucible and oven dried at $105^{\circ} \mathrm{C}$. The sample was weighed $\left(\mathrm{W}_{2}\right)$, and the percentage of lignin was calculated by the formula:

$$
\% \text { age of lignin }=\frac{\mathrm{W}_{2}}{\mathrm{~W}_{1}} \times 100
$$

\section{Cellulose Estimation}

Cellulose in the pretreated and untreated sample was estimated according to standard method [12]. One gram of sample (W1) was taken in a $250 \mathrm{ml}$ round bottom digestion flask, and $30 \mathrm{ml}$ of $80 \%$ acetic acid and $2 \mathrm{ml}$ of concentrated nitric acid were added. The sample was 
refluxed for $20 \mathrm{~min}$ and washed, filtered, and diluted with distilled water. The sample was then filtered with filter paper. Residues were taken in crucible and oven dried at $105^{\circ} \mathrm{C}$ overnight. The residues were weighed the next day (W2). The sample was charred for ash in a muffle furnace at $550^{\circ} \mathrm{C}$ for 6 hours and weighed again (W3). The percentage cellulose concentration was calculated through the formula:

$$
\begin{aligned}
& \% \text { age cellulose (Dry matter basis) } \\
& \qquad=\frac{\mathrm{W}_{2}-\mathrm{W}_{3}}{\mathrm{~W}_{1}} \times 100
\end{aligned}
$$

$\mathrm{W}_{1}=$ Weight of material on dry basis

$\mathrm{W}_{2}=$ Weight of digested material

$\mathrm{W}_{3}=$ Weight of ash

\section{Analytical Methods}

\section{Estimation of Total Sugars}

Total sugar content was measured according to the standard method [13]. For this, $1 \mathrm{ml}$ of the filtrate was taken in test tube along with $1 \mathrm{ml}$ of $5 \%$ phenol, mixed, and $5 \mathrm{ml}$ of concentrated $\mathrm{H}_{2} \mathrm{SO}_{4}$ was added. It was allowed for gently mixing for $20 \mathrm{~min}$ at room temperature $\left(25-35^{\circ} \mathrm{C}\right)$. The absorbance of sample was taken at $470 \mathrm{~nm}$ against blank.

\section{Estimation of Reducing Sugars}

DNS method [14] was used to test the presence of free carbonyl group $(\mathrm{C}=\mathrm{O})$, the so-called reducing sugars. This involves the oxidation of the aldehyde functional group present in glucose. Simultaneously 3, 5- dinitrosalicyclic acid is reduced to 3-amino, 5- nitrosalicyclic acid under alkaline conditions. One $\mathrm{ml}$ of filtrate was taken in test tube, $2 \mathrm{ml}$ of distilled water, and $3 \mathrm{ml}$ of DNS reagent was added and boiled in water bath for $10 \mathrm{~min}$. After cooling the filtrate to room temperature, the absorbance of sample was taken at $550 \mathrm{~nm}$ using glucose as standard.

\section{Glucose Estimation}

The glucose was measured by using the diagnostic kit (Cat. No. 0018) PCSIR Laboratories Complex, Karachi. The kit contained reagent 1 (buffer/enzyme) and reagent 2 (standard glucose solution). The sample, standard, and blank was prepared according to the prescribed method (using kit). Readings were taken at $546 \mathrm{~nm}$ in a Labomed, Inc. spectrophotometer (UVS-2800) to measure the optical density (OD) of each solution. The glucose was estimated by using the following formula:

Glucose concentration $=\frac{\text { Sample }(\text { Absorbance })}{\text { Standard (Absorbance) }} \times 100$

\section{Cellulase Enzyme Production}

Three different media compositions were used for the production of cellulase enzyme using pretreated lignocellulosic material as carbon source. Among these three media $\mathrm{ml}\left(\left(\mathrm{NH}_{4}\right)_{2} \mathrm{SO}_{4} 0.6 \%, \mathrm{NaCl} 0.5 \%, \mathrm{KH}_{2} \mathrm{PO}_{4}\right.$ $0.3 \%, \mathrm{MgSO}_{4} .7 \mathrm{H}_{2} \mathrm{O}$, pretreated yard waste substrate $1 \%), \mathrm{m} 2\left(\mathrm{KH}_{2} \mathrm{PO}_{4} 0.2 \%, \mathrm{~K}_{2} \mathrm{HPO}_{4} 0.7 \%, \mathrm{MgSO}_{4} 0.02 \%\right.$, $\mathrm{NaCl} 0.1 \%$, yeast extract $0.1 \%,\left(\mathrm{NH}_{4}\right)_{2} \mathrm{SO}_{4} 0.2 \%$, FeSO 4 , pretreated yard waste substrate $1 \%)$, and $\mathrm{m} 3\left(\mathrm{MgSO}_{4}\right.$ $0.03 \%, \mathrm{~K}_{2} \mathrm{HPO}_{4} 0.2 \%,\left(\mathrm{NH}_{4}\right)_{2} \mathrm{SO}_{4} 0.25 \%$, Pepton $1 \%$, yeast extract $0.6 \%$, pretreated yard waste substrate $1 \%$ ), which showed that maximum cellulase yield was used for further sacchrification process.

\section{Inoculum Development}

To the slants of 5-day-old cultures $1 \mathrm{ml}$ of sterilized distilled water was added. The spores were dislodged to make homogeneous spore suspension. The spore count was adjusted to $5.8 \times 10^{8}$ spores $/ \mathrm{ml}$ by Haemocytometer. One $\mathrm{ml}$ of this suspension was used as inoculum for $100 \mathrm{ml}$ production medium.

\section{Fermentation Protocol}

Fermentation medium of $100 \mathrm{ml}$ was prepared using medium composition $\mathrm{m} 1, \mathrm{~m} 2$, and $\mathrm{m} 3$, then autoclaved at $121^{\circ} \mathrm{C}$ for $15 \mathrm{~min}$. After sterilization, the medium was allowed to cool at room temperature, inoculated with $1 \mathrm{ml}$ of selected bacterial isolate, and incubated in a shaker (Eyela NTS- 331) at $35^{\circ} \mathrm{C}$ for $24 \mathrm{~h}$ of fermentation at $140 \mathrm{rpm}$ agitation. After termination of the fermentation period the fermented broth was centrifuged at 7,000 rpm for $15 \mathrm{~min}$ at $4^{\circ} \mathrm{C}$ to remove the residual material. The clear supernatant obtained after centrifugation served as a crude enzyme source.

\section{Estimating Cellulase Activity}

\section{Assay of CMCase}

The CMCase activity in the culture filtrate was assayed by incubating $1 \mathrm{ml}$ of crude enzyme solution with $1 \% \mathrm{CMC}$ solubilized in $0.05 \mathrm{M}$ phosphate buffer $(\mathrm{pH} 7.0)$ at $50^{\circ} \mathrm{C}$ for $30 \mathrm{~min}$. DNS was added in the reaction mixture boiled for 10 minutes. Reducing sugars were estimated by the DNS method [14].

\section{Assay of FPase}

Filter paper degrading activity in the centrifugal supernatant was determined by taking $1 \mathrm{ml}$ of crude cellulase fraction. A Whatman No. 1 filter paper strip was immersed in $1 \% \mathrm{CMC}$ in $0.05 \mathrm{M}$ phosphate buffer, $\mathrm{pH} 7.0$ [15], and $1 \mathrm{ml}$ of crude cellulase. After incubation at $50^{\circ} \mathrm{C}$ for $60 \mathrm{~min}$, the reducing sugar released will be carried out by the DNS method [14]. 


\section{Enzymatic Hydrolysis}

Four grams of delignified sample (yard waste) was taken in $250 \mathrm{ml}$ Erlenmeyer flasks. The cellulase enzyme $(5 \mathrm{ml})$ and substrate $4 \mathrm{~g}$ in $0.05 \mathrm{M}$ citrate buffer of $\mathrm{pH} 4.8$ was added and incubated at $55^{\circ} \mathrm{C}$ for $2-3$ days. To prevent possible micro-organism contamination, $400 \mathrm{mg}$ of $10 \mathrm{mg} / \mathrm{ml}$ tetracycline antibiotic in $70 \%$ ethanol and $300 \mathrm{mg}$ of $10 \mathrm{mg} / \mathrm{ml}$ cyclohexamide in DI water were added to the hydrolysis broth before adding enzymes. After each day total sugars, reducing sugars, and glucose testing was performed.

\section{Optimizing Enzymatic Hydrolysis}

The following process parameters were optimized to get a maximum of sugars from the substrate.

\section{Effect of Temperature on Hydrolysis}

During this work we evaluated incubation temperatures of $50,55,60,65$, and $70^{\circ} \mathrm{C}$, keeping all other parameters constant; total sugar, reducing sugar, and glucose content were estimated.

\section{Effect of Time on Hydrolysis}

The incubation periods $24 \mathrm{~h}, 48 \mathrm{~h}, 72 \mathrm{~h}, 96 \mathrm{~h}, 120$ $\mathrm{h}$, and $144 \mathrm{~h}$ were evaluated while all other parameters were kept constant; total sugar, reducing sugar, and glucose content were estimated.

\section{Effect of Substrate Concentration on Hydrolysis}

The substrate concentrations $2 \mathrm{gcm}^{-3}, 3 \mathrm{gcm}^{-3}$, $4 \mathrm{gcm}^{-3}, 5 \mathrm{gcm}^{-3}$, and $6 \mathrm{gcm}^{-3}$, respectively, were evaluated while all other parameters were kept constant to find the total sugar, reducing sugar, and glucose contents.

\section{Effect of Enzyme Concentration on Hydrolysis}

The enzyme concentrations of $3 \%, 4 \%, 5 \%, 6 \%$, and $7 \%$ by volume, respectively, were evaluated while all other parameters were kept constant to estimate total sugar, reducing sugar, and glucose content.

\section{Effect of pH on Hydrolysis}

The effect of $\mathrm{pH}$ on cellulose hydrolysis was evaluated by conducting experiments on different $\mathrm{pH}$, including 4.0, 4.5, 5.0, 5.5, and 6.0, while all other parameters were kept constant, like temperature of substrate maintained at room temperature. Diluted samples of $50 \mathrm{ml}$ each were prepared and their $\mathrm{pH}$ was adjusted along with control to compare the effect of $\mathrm{pH}$ on hydrolysis.

\section{Effect of Surfactants}

The tested additives (surfactants) were non-ionic detergent (Tween 20 and Tween 80), Polyethylene glycol (PEG 3350), SDS (Sodium dodecyl sulfate), and triton $\mathrm{X} 100$. The surfactant concentration was $0.1 \%(\mathrm{w} / \mathrm{w})$. The conditions for the enzymatic hydrolysis with surfactants were the same as in the hydrolysis without surfactants. All experiments were performed in triplicate.

\section{Results}

\section{Plate Screening for Cellulase Enzyme}

All bacterial strains were streaked on CMC agar plates and incubated at $35^{\circ} \mathrm{C}$ for 2 days to allow for the secretion of cellulase. After washing each incubated plate with Congo red dye and $1 \mathrm{M} \mathrm{NaCl}$ solution, zones of various diameters were obtained for each strain of Bacillus (Fig. 1).

The formation of zones indicated that all the bacillus strains contain cellulases, which effectively degrade CMC. The best/largest zone was formed by PC-BC6, showing 7.75 cellulolytic index, while on other hand PC-BC1, PC-BC3, PC-BC4, and PC-BC8 exhibited $4.83,3.13,3.47$, and 5.40 cellulolytic index, respectively. So PC-BC6 was chosen for the forthcoming sachharification studies. The experiment was repeated 3 times with all strains.

\section{Substrate Estimation}

Yard waste substrate was treated with $2.5 \% \mathrm{NaOH}$ to de-lignify the substrate and expose the cellulose for enzyme to hydrolyze and produce the reducing sugar

Table 1. Proximate analysis of untreated and treated yard waste.

\begin{tabular}{|c|c|c|c|c|}
\hline \multirow{2}{*}{ Substrate } & \multicolumn{4}{|c|}{ Content } \\
\cline { 2 - 5 } & Lignin (\%) & Cellulose (\%) & Ash (\%) & Moisture (\%) \\
\hline Untreated & $18.4 \pm 0.4$ & $46.7 \pm 0.1$ & $2.2 \pm 0.2$ & $5.2 \pm 0.2$ \\
\hline Treated & $5.7 \pm 0.3$ & $79.1 \pm 0.3$ & $4.6 \pm 0.1$ & $7.5 \pm 0.4$ \\
\hline
\end{tabular}

\pm Sign indicates the S.D among three replicates 


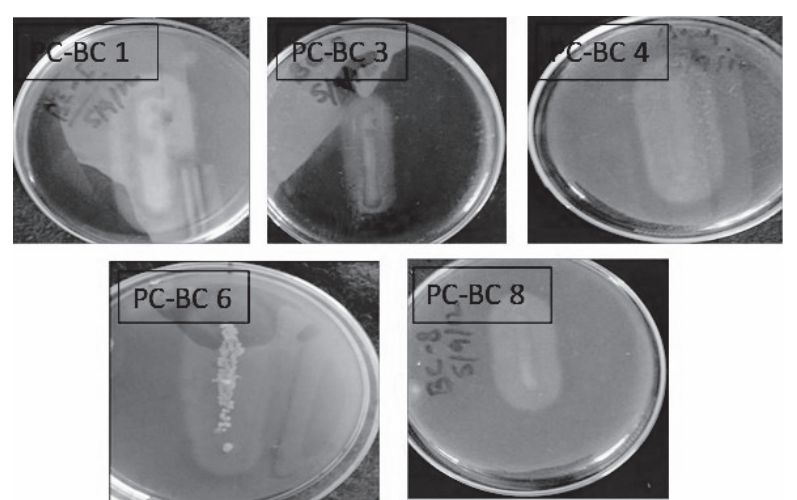

Fig. 1. Plate screening assay showing the formation of clear zones by different bacillus strains.

and glucose, which was further used in the fermentation process. The compositions of the untreated and treated substrates were determined by performing the standard method for percentage moisture, ash, lignin, and cellulose content; compositional analysis is given in Table 1. Results show that the lignin, cellulose, ash, and moisture contents of untreated substrate were $18.4 \pm 0.4,46.7 \pm 0.1,2.2 \pm 0.2$, and $5.2 \pm 0.2$, respectively, and for treated substrate was $79.1 \pm 0.3,5.7 \pm 0.3,4.6 \pm 0.1$, and $7.5 \pm 0.4$, respectively. The chemical composition of yard waste was found to vary according to its growth location, components, and the season, as well as analysis procedure.

\section{Cellulase Enzyme Production in Flasks}

The cellulosilyticus strain (PC-BC6) was screened for cellulase enzyme production in the submerged fermentation process. Among the three media tested, $\mathrm{m}^{3}$ revealed maximum cellulase yield, which was further used for sacchrification process. The enzyme extract obtained from filtration of the flask mixture was tested for CMCase and FPase activities, and results obtained are displayed in Fig. 2. The results revealed that the selected bacillus strain produced the highest amounts of FPase $(1,621.16 \mathrm{IU} / \mathrm{ml} / \mathrm{min})$ and CMCase $(1,998.79$ $\mathrm{IU} / \mathrm{ml} / \mathrm{min}$ ) for $\mathrm{m}^{3}$.

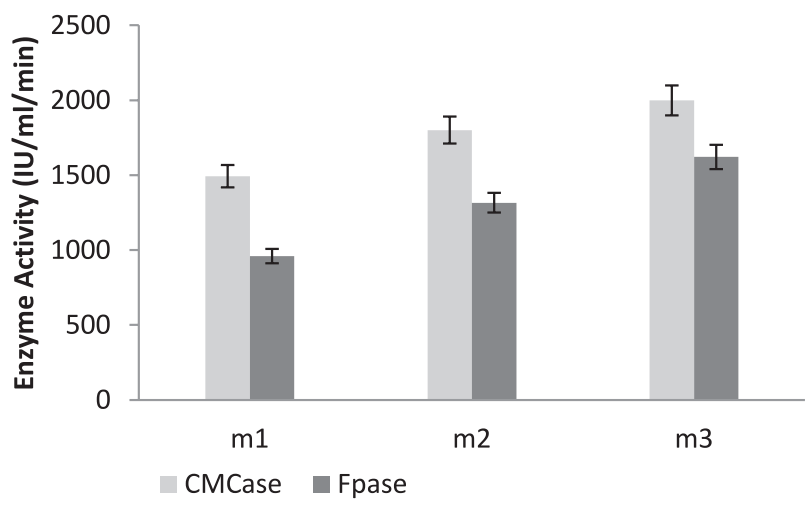

Fig. 2. Cellulolytic activity of PC-BC6 on different fermentation media.

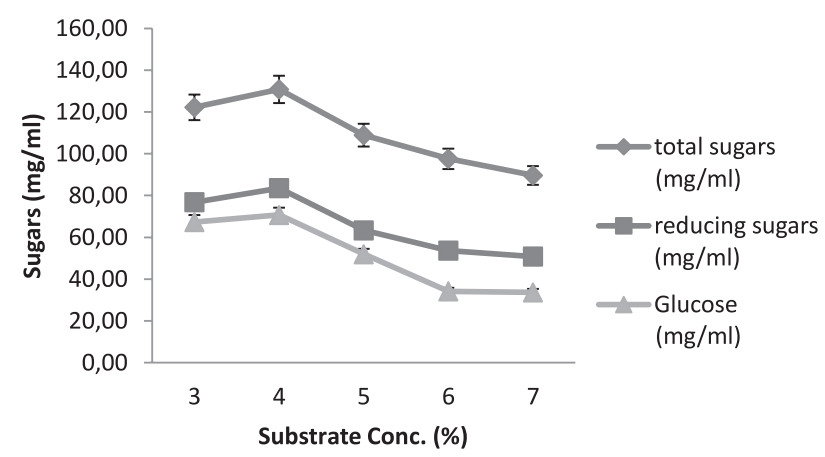

Fig. 3. Effect of various time intervals on hydrolysis of pretreated substrate.

\section{Enzymatic Hydrolysis}

The enzymatic breakdown of treated substrate was carried out with laboratory-scale crude cellulase enzyme produced from cellulosilyticus under controlled fermentation to optimize various parameters.

\section{Effect of Various Time Intervals on Hydrolysis of Pretreated Substrate}

The hydrolysis of pretreated yard waste was performed with crude cellulase enzyme at different time periods for determining optimum time. The time effect on the enzyme was significant to the hydrolysis of the substrate as presented in Fig. 3. The results indicated that out of different time ranges, $48 \mathrm{~h}$ was the optimum time period for enzymatic hydrolysis of yard waste to produce the maximum sugars in the form of total sugars $(123.03 \pm 0.3 \mathrm{mg} / \mathrm{ml})$, reducing sugars $(76.82 \pm 0.4 \mathrm{mg} / \mathrm{ml})$, and glucose $(67.33 \pm 0.1 \mathrm{mg} / \mathrm{ml})$. Further increases in the time period resulted in decreased enzymatic hydrolysis.

\section{Effect of Various Substrate Concentrations on Hydrolysis of Pretreated Substrate}

The suitable substrate concentration is crucial for digestion of substrate with enzyme substrate complex to produce the maximum product. The

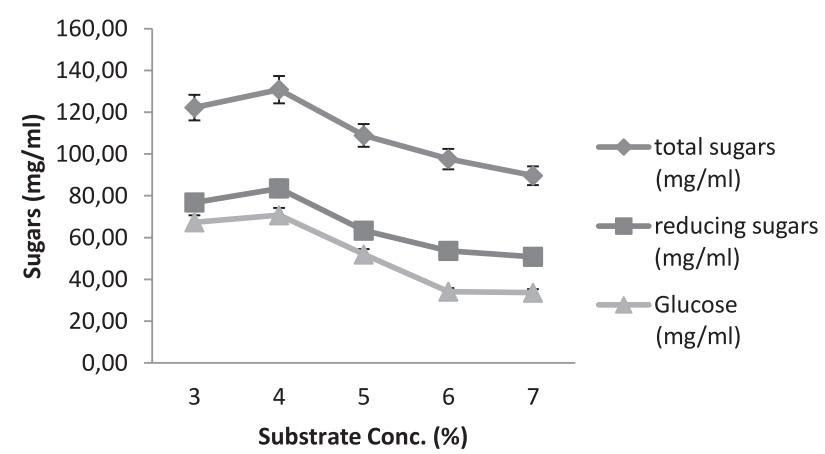

Fig. 4. Effect of various substrate concentrations on hydrolysis of pretreated substrate. 


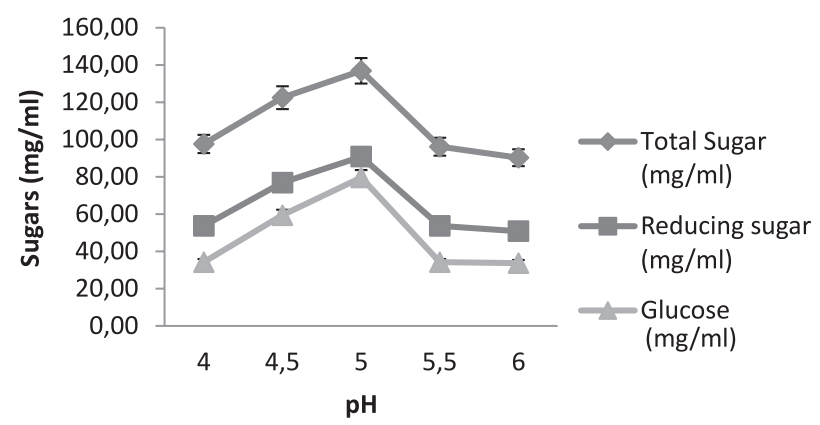

Fig. 5. Effect of $\mathrm{pH}$ on hydrolysis of pretreated substrate.

results presented in Fig. 4 indicated that among the various concentrations of pretreated substrate, $4 \%$ substrate concentration was found to be optimum. The substrate was found to release the maximum amounts of total sugars $(130.80 \pm 0.1 \mathrm{mg} / \mathrm{ml})$, reducing sugars $(83.55 \pm 0.1 \mathrm{mg} / \mathrm{ml})$, and glucose $(70.68 \pm 0.4 \mathrm{mg} / \mathrm{ml})$ at $4 \%$ substrate concentration. Further increases in substrate concentration retarded enzymatic hydrolysis.

\section{Effect of Various $\mathrm{pH}$ on Hydrolysis of Pretreated Substrate}

The enzymatic hydrolysis of substrate was performed with crude cellulase enzyme at different $\mathrm{pH}$ ranges for evaluating the optimum range for hydrolysis of biomass to digest the cell wall component. $\mathrm{pH}$ has a significant effect on the enzyme activity to induce the enzyme to catalyze the reaction (Fig. 5). The results of the study revealed that out of different $\mathrm{pH}$ ranges, 5 was the optimum range of $\mathrm{pH}$ for enzymatic hydrolysis to produce the maximum amounts of total sugars $(136.83 \pm 0.4 \mathrm{mg} / \mathrm{ml})$, reducing sugars $(90.84 \pm 0.1 \mathrm{mg} / \mathrm{ml})$, and glucose $(79.61 \pm 0.4 \mathrm{mg} / \mathrm{ml})$.

\section{Effect of Various Enzyme Concentrations on Hydrolysis of Pretreated Substrate}

The enzyme loading on the substrate was critical for proper digestion of the substrate. The enzyme was loaded at various concentrations from $3 \%$ to $7 \%$

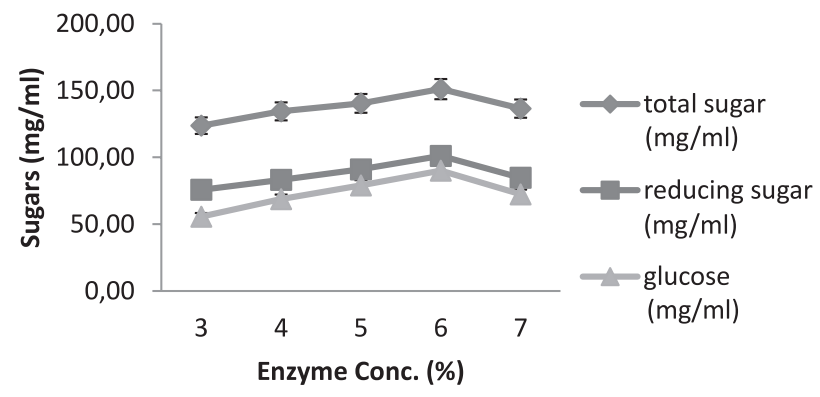

Fig. 6. Effect of various enzyme concentrations on hydrolysis of substrate.

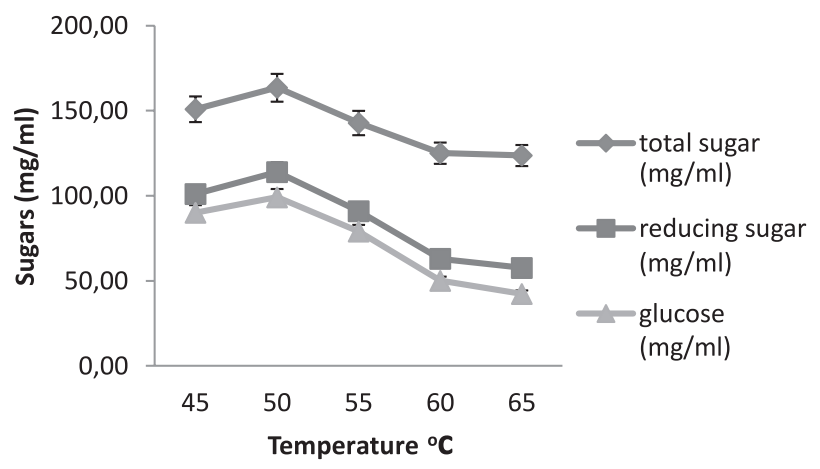

Fig. 7. Effect of temperature on hydrolysis of pretreated substrate.

(Fig. 6). The results of the enzyme loading indicated that there was progressive increase in production of total sugars, reducing sugars, and glucose up to $6 \%$ (1998.79 IU/ml $/ \mathrm{min}$ ) enzyme concentration per $4 \%$ substrate concentration and $6 \%$ enzyme concentration released the maximum sugars in the form of total sugars $(151.05 \pm 0.4 \mathrm{mg} / \mathrm{ml})$, reducing sugars $(101.06 \pm 0.1 \mathrm{mg} / \mathrm{ml})$, and glucose $(90.06 \pm 0.3 \mathrm{mg} / \mathrm{ml})$, while further increases in enzyme concentration suppressed sugar production.

\section{Effects of Different Temperatures on Hydrolysis of Pretreated Substrate}

The enzymatic hydrolysis of pretreated substrate was performed with crude cellulase enzyme at different temperature ranges to find the optimum range for hydrolysis of biomass. The temperature effect on enzyme activity was significant enough to induce the enzyme for full activation. The results presented in Fig. 7 depicted that out of different temperature ranges, $50^{\circ} \mathrm{C}$ was the optimum temperature for releasing maximum sugars in the form of total sugars $(163.52 \pm 0.3 \mathrm{mg} / \mathrm{ml})$, reducing sugars $(113.96 \pm 0.1 \mathrm{mg} / \mathrm{ml})$, and glucose $(99.10 \pm 0.3 \mathrm{mg} / \mathrm{ml})$. A gradual decline in sugar production was noticed by an increase in temperature (Fig. 7).

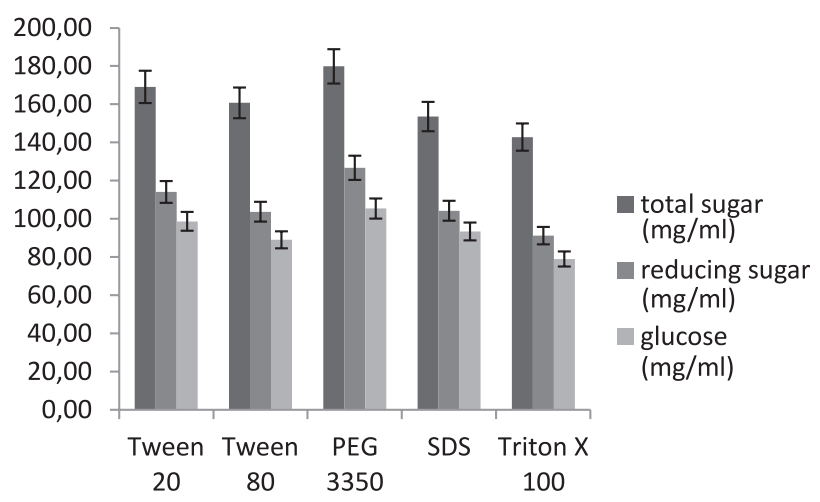

Fig. 8. Effect of various surfactants on hydrolysis of pretreated substrate. 


\section{Effect of Various Surfactants on Hydrolysis of Pretreated Substrate}

A surfactant's addition during enzymatic hydrolysis is accomplished by minimizing the irreversible binding of cellulase on cellulose and modifying the cellulose surface property. In the present study, the surfactants used in the enzymatic hydrolysis include Tween 20, Tween 80, PEG 3350, SDS, and Triton X100 (Fig. 8). It was observed from the results that the concentration of sugars improved maximum by using PEG 3350, followed by Tween 20. The maximum yield of sugars in the form of total sugars, reducing sugars, and glucose at $48 \mathrm{~h}$ incubation time, $50^{\circ} \mathrm{C}$, $5 \mathrm{pH}, 6 \%$ enzyme concentration, and $4 \%$ substrate concentration was $179.84 \pm 0.2 \mathrm{mg} / \mathrm{ml}, 126.72 \pm 0.1 \mathrm{mg} / \mathrm{ml}$, and $105.40 \pm 0.1 \mathrm{mg} / \mathrm{ml}$, respectively.

\section{Discussion}

Cellulose hydrolysis is currently carried out using microbial cellulolytic enzymes. Enzymatic hydrolysis has demonstrated better results for subsequent fermentation because no degradation components of glucose are formed [16]. Cellulase research has been concentrated mostly in fungi but there is increasing interest in cellulase production by bacteria due to their higher growth rate, thermo-stable, and alkali-stable properties [17]. Bacillus cellulosilyticus, Alkaliphilic Bacillus species has important industrial applications due to its ability to produce alkaline enzymes such as cellulase [18]. It produces extracellular enzymes that are resistant to high $\mathrm{pH}$ and high temperature conditions [6, 19-21].

For the sake of efficient and rapid hydrolysis of carbohydrates the lignocellulosic material or raw material must be pretreated $[9,22]$. Lignin should be removed before enzymatic hydrolysis because it acts as a protective physical barrier for cellulose to degrade in sugars and for removal of lignin alkali-pretreatment is carried out because it effectively retains most of the cellulose and removes the major portion of lignin [9, 23]. In this research work, we treated substrate with $2.5 \% \mathrm{NaOH}$ solution to delignify the yard waste and expose the maximum cellulose for the attack of enzyme to hydrolyze the cellulose and produce sugars and glucose.

Three different media were used for the production of cellulase enzyme in this study, from which $\mathrm{m}^{3}$ $\left(\begin{array}{llll}\mathrm{MgSO}_{4} & 0.03 \%\end{array}, \mathrm{~K}_{2} \mathrm{HPO}_{4} \quad 0.2 \%,\left(\mathrm{NH}_{4}\right)_{2} \mathrm{SO}_{4} \quad 0.25 \%\right.$, Pepton 1\%, Yeast Extract 0.6\%, carbon source, i.e., Pretreated yard waste $1 \%$ ) was optimized. With $\mathrm{m}^{3}$ media cellulase enzyme showed the greatest CMCase $(1998.79 \mathrm{IU} / \mathrm{ml} / \mathrm{min})$ and FPase $(1621.16 \mathrm{IU} / \mathrm{ml} / \mathrm{min})$ value. Favorable fermentation conditions and a selection of suitable growth medium played a key role in the production of cellulose [10, 24].

Factors that usually affect the enzymatic hydrolysis process of cellulose include cellulase activity, substrate concentration, and reaction conditions like temperature, $\mathrm{pH}$, and reaction time. To improve the rate and yield of saccharification or enzymatic hydrolysis, research should focus on optimizing the saccharification process [25-26]. In the present research work, among the various parameters, the loading of various enzyme concentrations during the saccharification of $2.5 \%$ $\mathrm{NaOH}$-treated yard waste showed a significant effect. Cellulase enzyme loadings vary dramatically due to substrate chemical composition, pretreatment method, inhibitory compounds, and enzyme activity in the process. A study was conducted in which it was investigated that in the process of lignocelluloses saccharification with multi-enzyme their hydrolytic efficiency depends on the individual properties of enzyme [27-28] and multi-enzyme ratio [29-30]. Substrate concentration is one of the main factors that affect the initial rate of enzymatic saccharification of cellulose and an increase of substrate concentration normally results in an increase of reaction rate of the hydrolysis [31-32]. However, high substrate concentration, which substantially lowers the rate of the hydrolysis, can cause its inhibition [33-36].

The result of the temperature optimization indicated that out of different temperature ranges, $50^{\circ} \mathrm{C}$ was the optimum temperature range for saccharification of treated substrate with cellulase enzyme for the release of maximum sugars. Maximum hydrolysis of alkali-treated substrates occurred at $50^{\circ} \mathrm{C}$, which counted the degree of saccharification of $37.29 \%$ and decreased at $60^{\circ} \mathrm{C}$, which counted to a degree of saccharification of $33.11 \%$ [37].

Results predicted that out of different $\mathrm{pH}$ ranges, $\mathrm{pH} 5$ was the optimum for enzymatic saccharification of alkali-pretreated substrate in the form of total sugars $\quad(136.83 \pm 0.4 \mathrm{mg} / \mathrm{ml})$, reducing sugars $(90.84 \pm 0.1 \mathrm{mg} / \mathrm{ml})$, and glucose $(79.61 \pm 0.4 \mathrm{mg} / \mathrm{ml})$. It was reported in a similar study that enzymatic hydrolysis carried out at $50^{\circ} \mathrm{C}$ and $\mathrm{pH} 4.8$ for $96 \mathrm{~h}$ and $58 \%$ yield was obtained, and $14.4 \%$ glucose for corn and stover, $13.1 \%$ glucose for straw of wheat [38-39]. In a parallel study [40-41], evaluated enzymatic hydrolysis of wheat straw for the conversion of cellulose and hemicelluloses into maximum monomeric sugars and reported that maximum yield of monomeric sugars $(565 \pm 10 \mathrm{mg} / \mathrm{g})$ was obtained at $45^{\circ} \mathrm{C}$ temperature and $\mathrm{pH} 5.0$ for $72 \mathrm{~h}$ by using cellulase.

Reaction time is also related with the process scale-up. The fermentable sugars obtained from the hydrolysis process could be fermented into ethanol. The results were indicated that out of different time ranges 48 hours was the optimum time period for enzymatic hydrolysis of treated substrate (yard waste) to produce the monomeric sugars in the form of total sugars $(123.03 \pm 0.3 \mathrm{mg} / \mathrm{ml})$, reducing sugars $(76.82 \pm 0.4 \mathrm{mg} / \mathrm{ml})$, and glucose $(67.33 \pm 0.1 \mathrm{mg} / \mathrm{ml})$ (Fig. 2). It was reported that cellulosic biomass was highly digestible after the pretreatment with yield of $90 \%$, less than 5 days and 3 days, preferably with $10 \mathrm{fpu} / \mathrm{gm}$ cellulose [42-43]. 
Adding surfactant during enzymatic hydrolysis is accomplished by minimizing the irreversible binding of cellulase on cellulose and modifying the cellulose surface property. In the present study, the concentration of sugars improved the maximum by using PEG 3350, and then Tween 20 showed the highest peak. Recent studies show that enzymatic hydrolysis yield can be enhanced by using surfactants (Tween-20, Tween-80, PEG, or BSA) [33-35]. It has also been published that various surfactants are able to increase the stability of cellulase [44].

\section{Conclusion}

Crude enzyme was produced from Bacillus cellulosilyticus. Optimized enzymatic hydrolysis was obtained at $6 \%(\mathrm{v} / \mathrm{v})$ enzyme concentration, $50^{\circ} \mathrm{C}, 4 \%$ (w/v) substrate concentration, $48 \mathrm{~h}$ incubation time, $\mathrm{pH}$ 5.0, and PEG 3350 as surfactant for enhancing the glucose concentration. The maximum yield of sugars in the form of total sugars, reducing sugars, and glucose after optimizing the hydrolysis process was $179.84 \pm 0.2 \mathrm{mg} / \mathrm{ml}, \quad 126.72 \pm 0.1 \mathrm{mg} / \mathrm{ml}$, and $105.40 \pm 0.1$ $\mathrm{mg} / \mathrm{ml}$. Further study on this topic is still required to make the process economical on a commercial scale in Pakistan.

\section{Acknowledgements}

University of the Punjab, Lahore, Pakistan, is acknowledged for its financial support of this research.

\section{References}

1. BHAT M.K. Cellulases and related enzymes in biotechnology. Biotech. Adv. 18, 355, 2000.

2. ARIFFIN H., ABDULLAH N., KALSOM MSU., SHIRAI Y., HASSAN M.A. Production and Characterization of Cellulase by Bacillus Pumilus EB3. Int. J. Eng. Technol. 3, 47, 2006

3. DEKA D., BHARGAVI P., SHARMA A., GOYAL D., JAWED M., GOYAL A. Enhancement of Cellulase Activity from a New Strain of Bacillus subtilis by Medium Optimization and Analysis with Various Cellulosic Substrates. Enz. res. 151656, 2011.

4. PRABHAVATH N.M., AMARESH Y.S., NAIK M.K., MALLESH S.B., KUCHANUR P.H. Study of different temperature levels on radial growth and dry mycelial weight of Trichoderma spp. isolated from red gram based conservation agriculture ecosystem. International Journal of Plant Protection. 7 (2), 424, 2014.

5. RATHOD M.G., PATHAK A.P. Wealth from waste: Optimized alkaline protease production from agroindustrial residues by Bacillus alcalophilus LW8 and its biotechnological applications. Journal of Taibah University for Science. 8 (4), 307, 2014.

6. NOGI Y., TAKAMI H., HORIKOSHI K. Characterization of alkaliphilic Bacillus strains used in industry: proposal of five novel species. Int. J. Sys. Evo. Microbiol. 55, 2309 , 2005.

7. SELVI V.A., BANERJEE R., RAM L.C., SINGH G. Biodepolymerization of low rank Indian coal. World J. Microbiol. Biotechno. 25, 713, 2009.

8. MOSIER N., WYMAN C., DALE C., ELANDER R., LEE Y.Y., HOLTZAPPLE M., LADISCH M. Features of promising technologies for pretreatment of lignocellulosic biomass. Biores. Technol. 96, 673, 2005.

9. ZHANG J., WANG X.S., CHU D.Q., HE Y.Q., BAO J. Dry pretreatment of lignocellulose with extremely low steam and water usage for bioethanol production. Biores. Technol. 102, 4480, 2011.

10. IRFAN M., SAFDAR A., SYED Q., NADEEM M. Isolation and screening of cellulolytic bacteria from soil and optimization of cellulase production and activity. Turkish J. Biochem, 37 (3), 287, 2012.

11. AOAC Official Methods of Analysis of AOAC International, $18^{\text {th }}$ ed., 33.2.43 (method 990.19); 33.7.03 (method 926.08); 32.1.03 (method 925.10); 44.4.04 (method 969.38A); 37.1.12 (method 920.151A); 29.1.22 (method 950.27); 43.1.04 (method 986.21); 42.2.01 (method 967.19E); 39.1.03 (AOAC 985.14); 32.1.14 (method 922.06); 35.1.23 (method 948.15); 33.2.26 (method 989.05); 33.3.19 (method 995.19); 33.2.27 (AOAC 989.04); 33.2.27A (AOAC 2000.18); 33.2.31 (AOAC 972.16). AOAC International, Maryland, USA. 2005.

12. GOPAL K., RANJHA N. Laboratory manual for nutrition research. Ronland press (India) Pvt. Ltd. New Dehli. 1980.

13. DUBOIS M.K., GILS J.K., HANNITON P.A., ROBES., SMITH F. Use of phenol reagent for the determination of total sugar. Analyt. Chem. 28, 350, 1956.

14. MILLER G.L. Use of dinitrosalicyclic acid reagent for determination of reducing sugar. Biotechnol. Bioeng. Symp. 5, 193, 1959.

15. FUJIMOTO E., STEVENSON T.J., CHIEN C.B., BONKOWSKY J.L. Identification of a dopaminergic enhancer indicates complexity in vertebrate dopamine neuron phenotype specification. Dev. Bio. 352, 393, 2011.

16. SANCHEZ C., CARDONA A. Trends in biotechnological production of fuel ethanol from different feedstocks. Biores. Technol. 99, 5270, 2008.

17. SADHU S., MAITI T.K. Cellulase Production by Bacteria: A Review. British Microbiol. Res. J. 3 (3), 235, 2013.

18. HORIKOSHI K., Production of alkaline enzymes by alkalophilic microorganisms. Part I. Alkaline protease produced by Bacillus no. 221. Agric Biol Chem. 36, 1407, 1971.

19. NIELSEN P., FRITZE D., PRIEST F.G., Phenetic diversity of alkaliphilic Bacillus strains: proposal for nine new species. Microbiol. 141, 1745, 1995.

20. GOYAL V., MITTAL A., BHUWAL A.K., SINGH G., YADAV A., AGGARWAL N.K. Parametric optimization of cultural conditions for carboxymethyl cellulase production using pretreated rice straw by Bacillus sp. 313SI under stationary and shaking conditions. Biotechnology research international, 2014.

21. SETHI S., DATTA A., GUPTA B.L., GUPTA S. Optimization of cellulase production from bacteria isolated from soil. ISRN biotechnology, 2013.

22. ALCÁNTARA M.Á.B., DOBRUCHOWSKA J., AZADI P., GARCÍA B.D., MOLINA-HEREDIA F.P., REYES-SOSA F.M. Recalcitrant carbohydrates after enzymatic hydrolysis of pretreated lignocellulosic biomass. Biotechnology for Biofuels. 9 (1), 207, 2016. 
23. SATHITSUKSANOH N., SAWANT M., TRUONG Q., TAN J., CANLAS C.G., SUN N., ÇETINKOL Ö. How Alkyl Chain Length of Alcohols Affects Lignin Fractionation and Ionic Liquid Recycle During Lignocellulose Pretreatment. BioEnergy Research. 8 (3), 973, 2015.

24. GAUR R., TIWARI S. Isolation, production, purification and characterization of an organic-solvent-thermostable alkalophilic cellulase from Bacillus vallismortis RG-07. BMC biotechnology. 15 (1), 1, 2015.

25. MENG X., RAGAUSKAS A.J. Recent advances in understanding the role of cellulose accessibility in enzymatic hydrolysis of lignocellulosic substrates. Current opinion in biotechnology. 27, 150, 2014.

26. SUN Y., CHENG J., Hydrolysis of lignocellulosic materials for ethanol production: a review. Biores. Technol. 83, 1, 2002.

27. PÉREZ J.A., BALLESTEROS I., BALLESTEROS M., SÁEZ F., NEGRO MJ., MANZANARES P. Optimizing liquid hot water pretreatment conditions to enhance sugar recovery from wheat straw for fuel-ethanol production. Fuel. 87, 3640, 2008.

28. ORENCIO-TREJO M., DE LA TORRE-ZAVALA S., RODRIGUEZ-GARCIA A., AVILÉS-ARNAUT H., GASTELUM-ARELLANEZ A. Assessing the Performance of Bacterial Cellulases: the Use of Bacillus and Paenibacillus Strains as Enzyme Sources for Lignocellulose Saccharification. BioEnergy Research. 1-11, 2016.

29. BERLIN A., MAXIMENKO V., GILKES N., SADDLER J. Optimization of enzyme complexes for lignocellulose hydrolysis. Biotechnol. Bioeng. 97, 287, 2007.

30. ZHOU J., WANG Y., CHU J., LUO L., ZHUANG Y., ZHANG S. Optimization of cellulase mixture for efficient hydrolysis of steam-exploded corn stover by statistically designed experiments. Biores. Technol. 100, 819, 2009.

31. ANDALIB M., ELBESHBISHY E., MUSTAFA N., HAFEZ H., NAKHLA G., ZHU J. Performance of an anaerobic fluidized bed bioreactor (AnFBR) for digestion of primary municipal wastewater treatment biosolids and bioethanol thin stillage. Renewable Energy. 71, 276, 2014.

32. LE COSTAOUËC T., PAKARINEN A., VÁRNAI A., PURANEN T., VIIKARI L. The role of carbohydrate binding module (CBM) at high substrate consistency: comparison of Trichoderma reesei and Thermoascus aurantiacus Cel7A (CBHI) and Cel5A (EGII). Bioresource technology. 143, 196, 2013.

33. MA L., LI C., YANG Z., JIA W., ZHANG D., CHEN S. Kinetic studies on batch cultivation of Trichoderma reesei and application to enhance cellulase production by fedbatch fermentation. Journal of biotechnology. 166 (4), 192, 2013.

34. MAHAMUD M.R., GOMES D.J., Enzymatic Saccharification of Sugar Cane Bagasse by the Crude
Enzyme from Indigenous Fungi. J. Sci. Res. 4 (1), 227, 2012.

35. VINTILA T., DRAGOMIRESCU M., JURCOANE S., CAPRITA R., MAIU M. Production of cellulase by submerged andsolid-state cultures and yeasts selection for conversion of lignocellulose to ethanol. Romanian Biotechnol. Lett. 14(2), 4275, 2009.

36. HASUNUMA T., KONDO A. Consolidated bioprocessing and simultaneous saccharification and fermentation of lignocellulose to ethanol with thermotolerant yeast strains. Process Biochemistry. 47(9), 1287, 2012.

37. SAHA B.C., ITEN L.B., COTTA M.A., WU Y.V., Dilute acid pretreatment, enzymatic saccharification and fermentation of wheat straw to ethanol. Process. Biochem. 40, 3693, 2005.

38. YANG B., WYMAN C.E., Effect of xylan and lignin removal by batch and flowthrough pretreatment on the enzymatic digestibility of corn stover cellulose. Biotechnol Bioeng. 86 (1), 88, 2004.

39. LI H., PU Y., KUMAR R., RAGAUSKAS A. J., WYMAN C.E. Investigation of lignin deposition on cellulose during hydrothermal pretreatment, its effect on cellulose hydrolysis, and underlying mechanisms. Biotechnology and bioengineering. 111 (3), 485, 2014.

40. AVCI A., SAHA B.C., DIEN B.S., KENNEDY G.J., COTTA M.A. Response surface optimization of corn stover pretreatment using dilute phosphoric acid for enzymatic hydrolysis and ethanol production. Bioresource technology. 130, 603, 2013.

41. GAO X., KUMAR R., SINGH S., SIMMONS B.A., BALAN V., DALE B.E., WYMAN C.E. Comparison of enzymatic reactivity of corn stover solids prepared by dilute acid, AFEX ${ }^{\mathrm{TM}}$, and ionic liquid pretreatments. Biotechnology for biofuels. 7 (1), 1, 2014.

42. TABKA M.G., GIMBERT HI., MONOD F., ASTHER M., SIGOLLOT J.C. Enzymatic saccharification of wheat straw for bioethanol production by a combined cellulose xylanase and feruloyl esterase treatment. Enz. Microbial Technol. 39, 897, 2006.

43. GOVUMONI S.P., KOTI S., KOTHAGOUNI S.Y., VENKATESHWAR S., LINGA V.R. Evaluation of pretreatment methods for enzymatic saccharification of wheat straw for bioethanol production. Carbohydrate polymers. 91 (2), 646, 2013.

44. YAO R., QI B., DENG S., LIU N., PENG S., CUI Q. Use of surfactant in enzymatic hydrolysis of rice straw and lactic acid production from rice straw by simultaneous saccharification and fermentation. Biores. 2 (3), 38, 2007.

45. GOVUMONI S.P., KOTI S., KOTHAGOUNI S.Y., VENKATESHWAR S., LINGA V.R. Evaluation of pretreatment methods for enzymatic saccharification of wheat straw for bioethanol production. Carbohydrate polymers. 91 (2), 646, 2013. 
